\title{
Game Edukasi Pengolahan Limbah Tepung Mocaf Singkong "Ayo Bersihkan Limbah"
}

\author{
Nurwisnu Warasih Al-Kahfie ${ }^{* 1}$, Eko Budi Cahyono ${ }^{2}$, Wildan Suharso ${ }^{3}$ \\ 1,2,3Teknik Informatika/Universitas Muhammadiyah Malang \\ nurwisnu.wa@gmail.com*
}

\begin{abstract}
Abstrak
Singkong merupakan salah satu makanan kaya akan karbohidrat, selain itu terdapat kandungan gizi seperti protein, vitamin $C$, kalori, lemak. Pemanfaatan singkong lebih ke sumber pangan ada bagian lain dari singkong yang penggunaanya belum termanfaatkan secara optimal. Dari produksi yang begitu banyak dihasilkan berupa limbah cair hasil dari olahan tepung mocaf dari singkong dan pembuatan beras mocaf dari singkong. Air buangan limbah bila langsung dibuang akan mencemari lingkungan dan menghasilkan bau dari mikroba yang mati, namun limbah masih bisa dimanfaatkan menjadi pupuk. Telah dibentuk 6 tim untuk membantu penelitian terebut yang memiliki tugas berbeda-beda salah satunya Game edukasi pengolahan limbah tepung mocaf singkong "Ayo Bersihkan Limbah" dengan metode GDLC (Game Development Life Cycle) dengan genre simulasi dimana game ini mengajarkan cara pengolahan limbah tepung mocaf menjadi pupuk.
\end{abstract}

Kata Kunci: Singkong, Mocaf, Game, Simulasi, Edukasi

\section{Abstract}

Cassava is one of the foods rich in carbohydrates, in addition there are nutritional content such as protein, vitamin C, calories, fat. Cassava utilization is more to the food source there are other parts of cassava whose use has not been utilized optimally. From the production of so much produced in the form of liquid waste from processed mocaf flour from cassava and making mocaf rice from cassava. Waste water when discharged directly will pollute the environment and produce odor from the dead microbes, but the waste can still be used as fertilizer. 6 teams have been set up to help the research that has different tasks one of the Education edition of cassava mocaf waste processing waste "Come Waste Clean" with GDLC (Game Development Life Cycle) method with simulation genre where this game teaches how to waste mocaf waste processing into fertilizer.

Keywords: Cassava, Mocaf, Game, Simulation, Education

\section{Pendahuluan}

Singkong merupakan salah satu makanan kaya akan karbohidrat, selain itu terdapat kandungan gizi seperti protein, vitamin $\mathrm{C}$, kalsium posfor, kalori, lemak, zat besi dan vitamin $\mathrm{B}_{1}$ [1]. Karena pemanfaatan singkong lebih ke sumber pangan, maka perlu diperhatikan bagian lain dari singkong yang penggunaannya belum termanfaatkan secara optimal. Dari produksi singkong yang begitu banyak, dihasilkan limbah berupa limbah cair hasil dari olahan tepung mocaf dari singkong dan pembuatan beras mocaf dari singkong yang memiliki selulosa tinggi, dan juga biasanya dalam proses pembuatan tepung mocaf dan beras mocaf dari singkong dipergunakan air relative banyak [1].

Air buangan limbah bila langsung dibuang keperairan maka perairan akan kekurangan oksigen. Sehingga terjadi proses an-aerob yang mengakibatkan pencemaran lingkungan yang ditimbulkan oleh bau dari mikrobia yang mati dan mengalami pembusukan [2]. Namun limbah masih bisa dimanfaatkan kembali menjadi pupuk yang bergunak untuk tanaman singkong itu sendiri ataupun tanaman lainnya sehingga semua yang ada di tanaman singkong itu bisa dipergunakan semua [3]. Penelitian yang dilakukan di desa Tirtoyudo kecamatan Tirtoyudo kabupaten Malang sebagian besar pelaku usaha berbahan ubi kayu masih memiliki keterbatasan dalam beberapa hal, diantaranya keterbatasan akses informasi, akses modal dan akses pasar. Upaya untuk mengatasi dan menghilangkan keterbatasan tersebut, salah satunya dengan cara mengarahkan mereka untuk menggunakan perangkat teknologi informasi secara optimal [5]. 
Maka dari itu muncul pemikiran dari salah satu peneliti yaitu Eko Budi Cahyono untuk membuat sebuah tim yang berisi 6 orang untuk turut serta dalam proses penelitian tersebut. 6 tim yang saat ini masih dikerjakan disini dimaksudkan agar memudahkan proses pengenalan sekaligus motede pembelajaran kepada masyarakat agar lebih memahami bagaimana proses pengolahan singkong sampai dengan pengolahan limbah singkong itu sendiri hingga sampai dipasarkan[10].

Pada penulisan proposal ini penulis akan membahas tentang Game pengolahan limbah cair singkong menjadi pupuk "Ayo Bersihkan Limbah". Game edukasi sendiri merupakan game yang mendidik bagi para penggunanya yang tujuannya membuat permainan tidak jenuh dan tidak membosankan, dengan harapan game edukasi ini bisa mmebantu pola pikir masyarakat dalam gal memahami dan mengetahui cara pengolahan limbah singkong menjadi pupuk [4]. Genre yang dipilih dalam pembuatan game ini adalah game simulasi game dengan tipe simulasi dapat menggambarkan tentang kehidupan sehari-hari dan pengoprasian alat tertentu [5]. Metode yang digunakan dalam pebuatan game ini adalah GDLC (Game Development Life Cycle) [6]. Dengan mengadopsi beberapa game antara lain "Pipa Combate", "Where's My Water?", dan "City Garbage Truck Simulator".

Berdasarkan uraian diatas dapat disimpulkan rumusan masalah yang akan dihadapi yaitu bagaimana perancangan game "Ayo Bersihkan Limbah" pada platform android, bagaimana proses membangun game "Ayo Bersihkan Limbah" pada platform android.

\section{Metodelogi} berikut:

Tahapan-tahapan penelitian yang dilakukan untuk pembuatan tugas akhir ini sebagai

\subsection{Game}

Dalam bahasa Indonesia game diartikan sebagai permainan. Permainan adalah kegiatan kompleks yang didalamnya terdapat peraturan, play dan budaya. Sebuah permainan adalah sistem dimana pemain terlibat konflik buatan [7][8].

\subsection{Game Edukasi}

Game yang memiliki content pendidikan lebih dikenal dengan istilah game edukasi. Yang memiliki tujuan untuk memancing minat belajar anak terhadap materi pelajaran sambal bermain sehingga diharapkan anak lebih memahami materi yang disajikan. Game edukasi adalah salah satu bentuk game yang dapat berguna untuk menunjang proses belajar-mengajar secara lebih menyenangkan dan kreatif [9].

\subsection{Game Simulasi}

Game simulasi lebih merepresentasikan kehidupan semirip mungkin dengan kehidupan asli dan mengandalkan unsur gameplay dengan fitur-fitur sesuai dengan tema game.

\subsection{Game Development Life Cycle (GDLC)}

Game Development Life Cycle adalah sebuah metode pembangunan dan pengembangan game, dimana didalamnya ada tahapan initiation, pre-production, production, testing, beda dan release. Gambar 1 dibawah ini merupakan penjelesan singkat tentang tahapan-tahapan Game Development Life Cycle (GDLC).

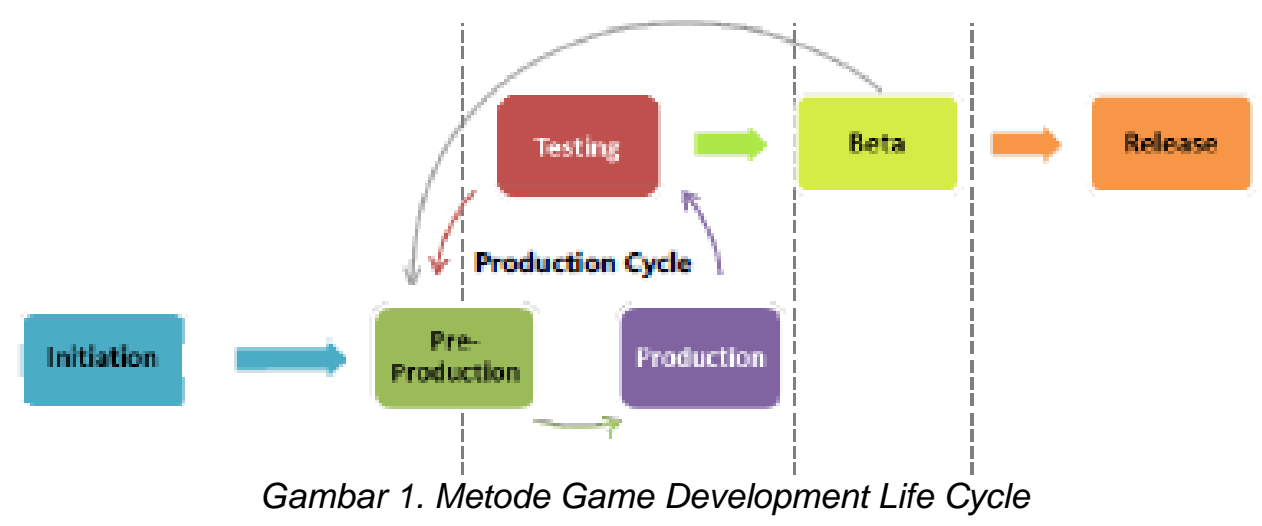

REPOSITOR, Vol. 2, No. 4, April 2020: 447-454 
a) Initiation

Pada tahap ini akan dilakukan pembuatan konsep game yang ingin dibangun, akan seperi apa game itu dibangun. Pada Initiation akan menghasilkan konsep game dan deskripsi sederhana game.

b) Pre-Production

Tahapan sebelum production yaitu tahapan untuk melakukan perancangan dan membuat desain game.

c) Production

Pada tahap ini adalah tahap produksi atau realisasi pembuatan game yang sudah didesai pada tahap pre-production.

d) Testing

Pada tahap ini akan dilakukan pengujian pada game yang sudah dibuat, pengujian dilakukan oleh internal tim untuk menguji. Pada testing akan menghasilkan laporan bug, pada hasil ini nantinya akan memutuskan apakah game sudah siap untuk memasuki beta testing atau mengulangi ke tahap pre-production.

e) Beta

Beta adalah pengujian lanjutan setelah testing yang diuji oleh internal tim dan sekarang akan di uji oleh external tim atau diluar tim.

f) Release

Pada tahap ini pembuatan game sudah mencapai tahap akhir dan berati game sudah siap di publish ke publik.

\subsubsection{Gameplay}

Cara bermain pada permainan yang akan dibuat ini yaitu pemain berinteraksi dengan permainan, pemain akan diperintahkan menekan beberapa tombol dilayar smartphone android untuk memainkan permainan ini terdapat beberapa tantangan berupa waktu di setiap langkahnya, apabila berhasil menyelesaikan permainan sesuai dengan instruksi maka pemain akan mendapat skor akhir. Gambar 2 berikut ini gameplay dari permainan.

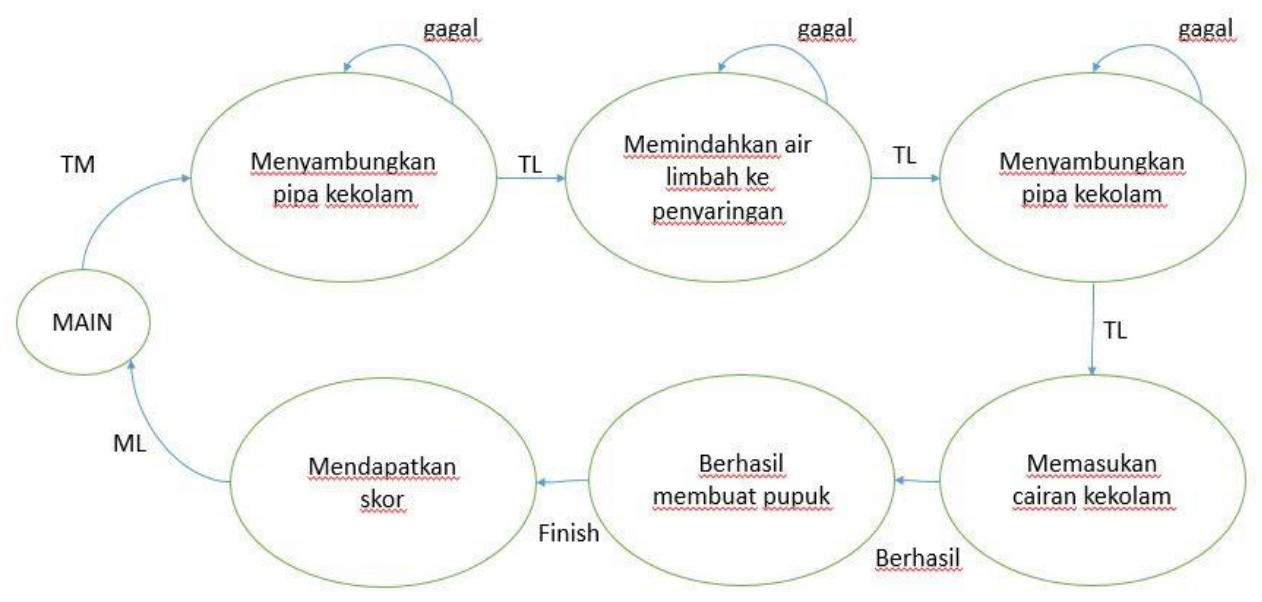

Gambar 2. FSM Gameplay

Keterangan :

TM : Tekan Tombol Main

TL : Tekan Lanjut

ML : Main Lagi

Gagal : Pemain tidak berhasil melakukan tahap permainan

Berhasil : Pemain berhasil membuat pupuk

Finish : Pemain Menyelesaikan Permainan 
Main adalah pada saat aplikasi berjalan lalu pemain masuk ke langkah pembuatan pupuk mulai dari merajang singkong, kemudian lanjut membuang air hasil fermentasi singkong ke kolam penampungan limbah, setelah itu pemain akan menyusun pipa untuk memindahkan air limbah dari kolam penampungan ke kolam penyaring, lalu pemain kembali menuyusn pipa untuk memindahkan lagi air hasil limbah hasil saringan ke kolam untuk memisahkan air dengan pasir, setelah itu pemain diperintahkan untuk mencari palang air yang sesuai dengan ukuranya untuk memindahkan air hasil pemisahan dengan pasir tadi ke tangki penampungan dan mengembalikan palang air dan menekan tombol merah untuk membuang pasir, kemudian pemain diminta untuk merakit mulai dari pipa oksigen, selang oksigen dan tabung oksigen kemudian menekan tombol on untuk menyalakn oksigen dan tombol off untuk mematikan oksigen. Oksigen dinyalakan untuk mengeluarkan minyak yang ada di air limbah dan mengangkat minyak dengan alat yang sudah disediakan. Lalu pemain memasukan cairan EM-4 jika tangki oksigen sudah bersih dari minyak dan meletakan kembali tabung oksigen, selang oksigen dan pipa oksigen kembali ketenpat semula dan merakit pipa sesuai dengan jumlah pipa yang telah disediakan jika sudah tersabung ke tangka air yang kosong tadi maka pemain menekan tombol agar air bisa mengalir kemudian memasukan cairan EM-4 untuk proses akhir pengolahan pupuk yang harus disesuaikan dengan indicator. Jika sudah proses pemasukan cairan EM-4 tadi berhasil maka proses pembuatan pupuk cair limbah singkong telah berhasil dilalui, kemudian pemain diminta untuk menyambungkan pipa dimana sudah diberikan rangka sehingga pemain tinggal menyesuaikan bentuk pipa untuk mengalirkan air pupuk ke botol dan siap untuk dipakai. Dan jika sudah menyelesaikan semuanya pemain akan mendapatkan skor.

\subsubsection{Desain}

Berikut ini merupakan rancangan game.

\subsubsection{1}

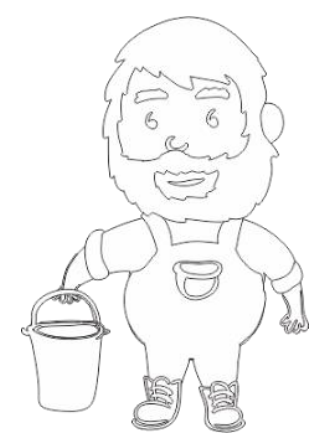

Gambar 3. Desain Pak Lim

Karakter utama pada Gambar 3 adalah karakter petani yang membawa ember ditangannya, yang bertugas untuk mengarahkan para pemain langkah-langkah untuk pengolahan limbah tepung mocaf singkong.

\subsubsection{Rancangan Alur Sistem}

Rancangan alur sistem dalam permainan ini akan menggunakan media gambar. Tujuan dari rancangan alur sistem ini adalah pemain dapat memahami alur dari sistem yang telag dirancang dengan melihat gambar-gambar yang sudah tersusun.

Pada Gambar 4, menu utama terdapat beberapa pilihan. Terdapat menu "pengaturan" dimana pemain dapat mengatur music dan suara aksi pada permainan. Pemaian dapat memulai permainan dengan mengisi nama terlebih dahulu dan memilih menu "Mulai", apabila ingin mengganti pemain dapat memilih "Ubah Pemain". Pada awal permainan, pemain akan terlebuh dahulu menjumpai Pak Lim yang akan menjelaskan setiap langkah bagaimana menyelesaikan permainan. Pada akhir permainan pemain akan melihat skor yang didapat dari permainan yang telah dilaluinya dan dapat memulai kembali permainan. Ada menu "Keluar" untuk keluar dari aplikasi.

REPOSITOR, Vol. 2, No. 4, April 2020: 447-454 


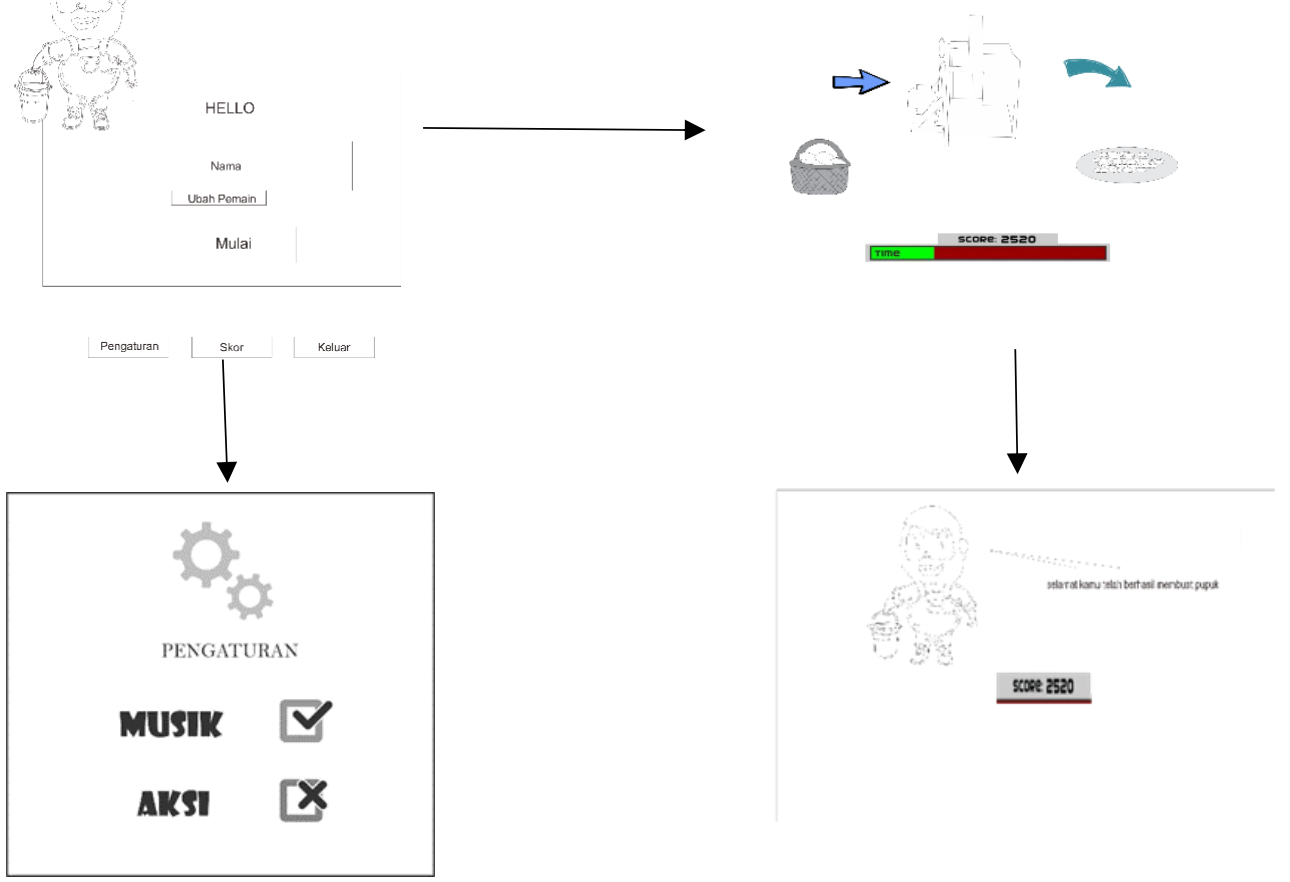

Gambar 4. Rancangan Alur Sistem

\section{Hasil Penelitian dan Pembahasan}

Pada tahap ini akan menjelaskan hasil pembuatan game yang sudah didesain pada tahap sebelumnya.

\subsection{Implementasi Karakter}

Berikut ini merupakan tampilan dari karakter, alat dan bahan pada permainan.

A. Karakter

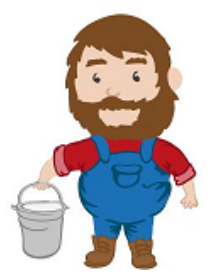

Gambar 5. Implementasi Pak Lim

Gambar 5 diatas merupakan implementasi tampilan dari Pak Lim yang telah didesain sebelumnya.

B. Alat dan Bahan

Berikut ini merupakan alat dan bahan yang ada pada game, mulai dari mesing perajang sinngkong, alat dan bahan.

1. Mesin Perajang Singkong

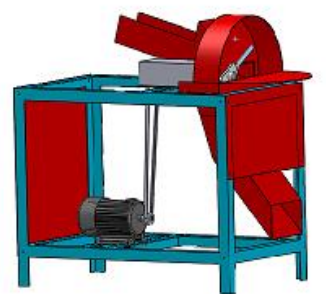

Gambar 6. Mesin Perajang Singkong 
Gambar 6 merupakan implementasi tampilan dari mesin pengupas singkong yang digunakan untuk memotong singkong menjadi bagian kecil yang disebut chips.

2. Pipa, gayung, dan EM-4
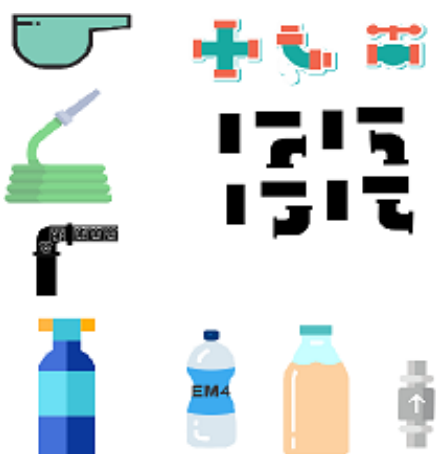

Gambar 7. Pipa, Selang dan Cairan EM-4

Gambar 7 menampilkan pemain akan menyusun pipa agar bisa tesambung dari kolam satu ke kolam lainya maupun dari tangki ke tangki lainya, dan gayung digunakan untuk mengambil cairan minyak yang muncul pada saat air limbah di masukan oksigen dengan cara menggayungnya, serta cairan EM-4 digunakan untuk proses akhir dari pembuatan pupuk.

\subsection{Implementasi Modul Antarmuka}

Pada Gambar 8 merupakan tampilan antarmuka akan menjabarkan tentang implementasi modul tampilan awal hingga bermain.

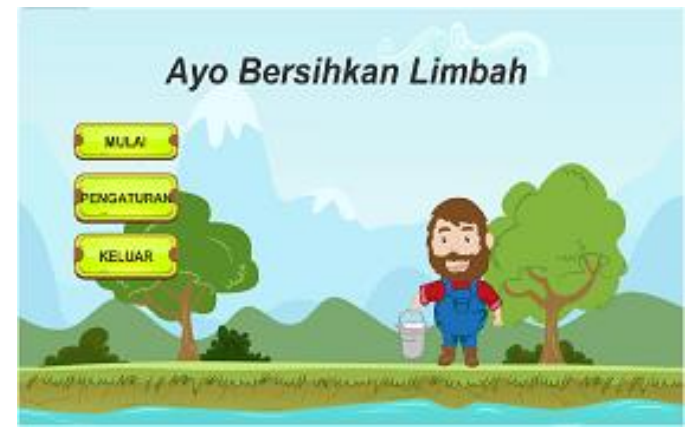

Gambar 8. Tampilan Awal

Pada tampilan awal pada Gambar 8, pemain dapat memilih menu main, menu pengaturan dan menu keluar.

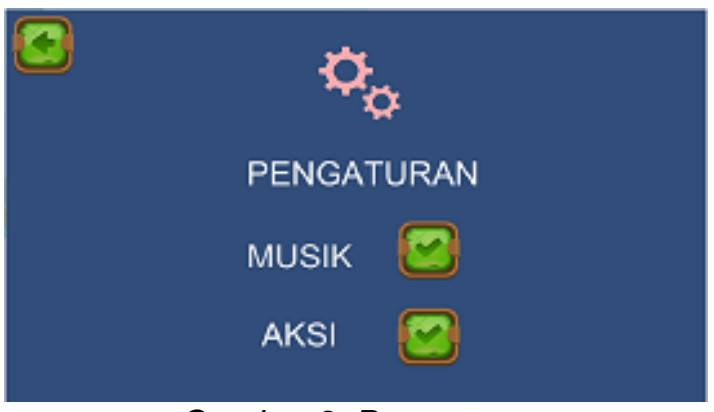

Gambar 9. Pengaturan

Pada Gambar 9 ketika pemain memilih menu pengaturan, maka pemain akan masuk ke tampilan pengaturan, pemain dapat menyalakan dan mematikan suara dalam game pada pengaturan yang terlihat pada Gambar 9. 


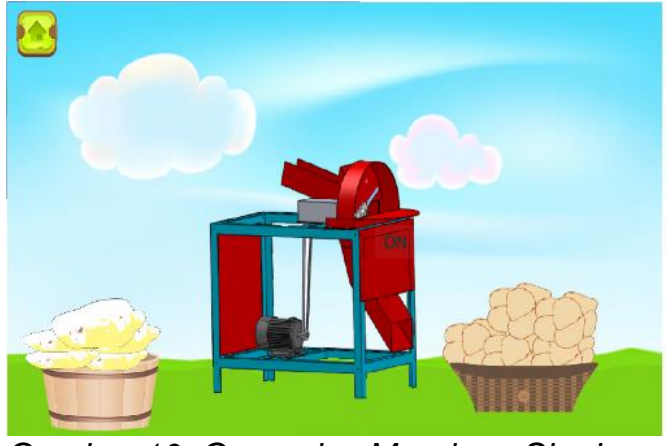

Gambar 10. Gameplay Merajang Singkong

Pemain yang memilih menu main akan masuk ke permainan proses merajang singkong terlihat pada Gambar 10, pemain diminta memasukan singkong ke mesin perajang untuk menghasilkan chips.

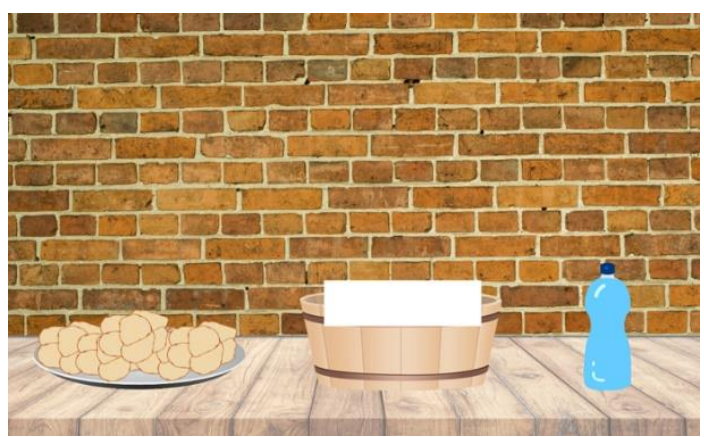

Gambar 11. Gameplay Fermentasi

Pada Gambar 11 ini adalah tampilan fermentasi, dimana semua singkong dimasukan kedalam ember dengan cara mendrag satu persatu singkong kemudian ember di isi air dengan cara memasukan air yang sudah tersedia di botol, kemudian pemain menunggu selama 5 detik agar proses fermentasi bisa berhasil dilakukan.

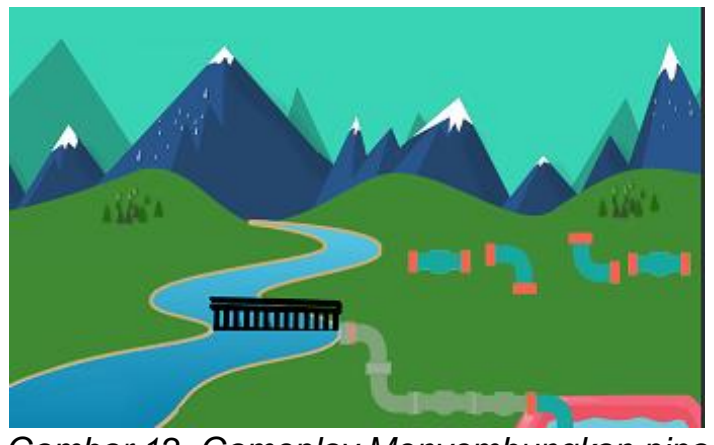

Gambar 12. Gameplay Menyembungkan pipa

Pada Gambar 12 ini adalah tampilan gameplay menghasilkan gelembung, dimana air yang sudah mengalir dan sudah tersaring pada tahap sebelumnya air limbah masih kotor dan mengandung minyak sehingga pemain untuk memasang selang, tabung oksigen, dan pipa berlubang kedalam tangki untuk menghasilkan gelembung-gelumbung minyak, kemudian minyak diambil menggunakan gayung yang sudah tersedia.

\section{Kesimpulan}

Setelah melalui pengerjaan implementasi dan pengujian terhadap sistem, dapat ditarik kesimpulan bahwa fungsionalitas pada aplikasi ini telah berfungsi sebagaimana yang diharapkan, dan pada alur permainan sudah berjalan dengan baik. Selain itu juga ada saran untuk penelitian lebih lanjut sehingga dapat dikembangkan dengan menghubungkan game ke internet, 
penambahan tingkat kesulitan dalam permainan yaitu apabila pemain gagal harus mengulang permainan, dan perlunya penambahan informasi yaitu pemberian gambar informasi tentang bagaimana mendapat hight score.

\section{Referensi}

[1] Elvina Novyanti Pulungan, Albiner Siagian, and Ernawati Nasution“Uji Daya Terima Dan Nilai Gizi Brownies Singkong"

[2] P. Limbah and C. Mocaf, "AplikasI EM4 (Effective Microorganism) Dalam Pengolahan Limbah Cair Mocaf ( Modified Cassava Flour )," vol. 4, 2013.

[3] A. Subagio, W. Siti, and D. Hermanuadi, Pengembangan zero waste processing dari modified cassava flour (MOCAF) guna meningkatkan spinoff klaster kepada masyarakat sekitar [ Development of zero waste processing of modified cassava flour ( MOCAF) to increase the spinoff of the clusters to comm, no. September. 2011.

[4] Santoso Budi. "Proses Pengolahan Air Buangan Industri Tapioka," pp. 1-13, 1993.

[5] P. Studi, T. Informatika, F. Teknik, and U. M. Malang, "Pelaku Usaha Berbahan Baku Ubi Kayu," pp. 387-393, 2016.

[6] Daniel Hartono, Clarissa, and Margaretha Lamaranti "Perancangan Aplikasi Game Edukasi Advanture Puzzle Chemical Panic Berbasis Android," 2014.

[7] E. S. Kw et al., "Pembuatan Game Simulasi Perkebunan , Peternakan dan Interaksi Sosial," pp. 1-4.

[8] A. D. Wulandari, "Game Edukatif Sejarah Komputer Menggunakan Role Playing Game (RPG) Marker XP Sebagai Media Pembelajaran di SMP Negeri 2 Kalibawang," Game Edukatif Sej. Komput. Menggunakan Role Play. Game Marker XP Sebagai Media Pembelajaran di SMP Negeri 2 Kalibawang, 2012.

[9] R. Ramadan and Y. Widyani, "Game development life cycle guidelines," 2013 Int. Conf. Adv. Comput. Sci. Inf. Syst., no. September 2013, pp. 95-100, 2013.

[10] Subagio, Achmad "Pengembangan Zero Waste Processing Dari Modified Cassaa Flour (MOCAF) Guna Meningkatkan Klaster Kepada Masyarakat Sekitar," no. April, pp. 3-5, 2011. 